Review:

Charter Schools, Race, and Urban Space: Where the Market Meets Grassroots Resistance by Kristen Buras

Reviewed by Nicole Polier

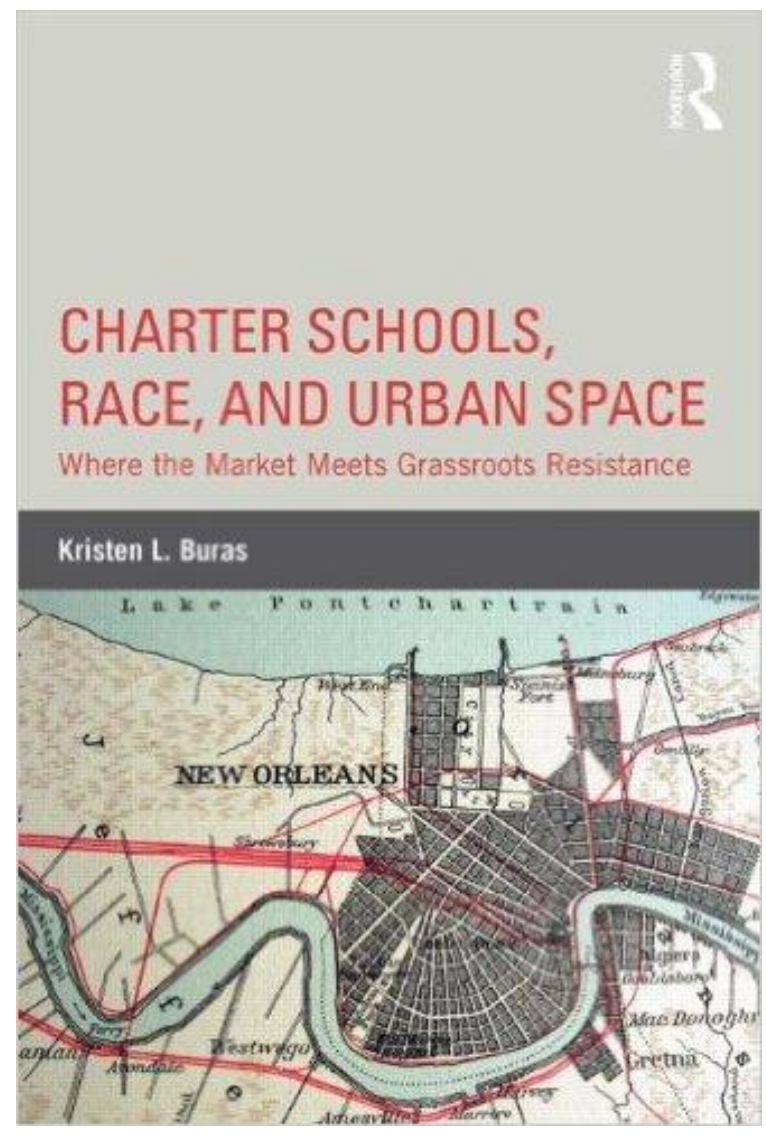




\section{Charter Schools, Race, and Urban Space: Where the Market Meets Grassroots Resistance (Routledge, 2015) by Kristen Buras}

\section{Reviewed by Nicole Polier}

If you believe Governor Chris Christie, New Jersey public schools are "broken and failing," and charters are "salvation for families, especially in failing urban districts." Lest there be any doubt whose side he's on, Christie threatened to veto any bills by legislators that "try to stick it to charter schools."

One can't help but notice how often the term "failing" is used to describe poor urban public schools and how "choice" has become shorthand for the salutary effects of charter reform. Never mind how schools get "broken" in the first place and how their "failure" has time and again, as if inevitably, led to privatization, figured as "choice." State takeovers of public schools are occurring most rapidly in poor and minority school districts in response to financial crisis: Jersey City in 1989, Paterson 1991, Newark 1995, Detroit 1999, Philadelphia 2001, Little Rock 2015, and the Louisiana Recovery School District in 2003, 93\% black and Latino, before the storm. Cities like New York, by contrast, have undergone charter reform at a more gradual pace.

Hurricane Katrina hit New Orleans at the end of August, 2005, and was the costliest natural disaster in U.S. history and among the deadliest, trashing the infrastructure and forcing populations to flee, some never to return. There was nothing natural about the mismanagement of the disaster at local, state, and federal levels. The response to destruction of New Orleans public schools, flooded and closed down after the storm, was rapid and well organized by contrast. Within a few months, the state of Louisiana nullified the collective bargaining agreement of the New Orleans teachers' union and handed over most schools to the Recovery School District (RSD), an entity created in 2003 to intervene in the governance of schools the state then considered to be failing. Legislatively, Act 35, passed in November 2005, was a mechanism for transferring failing schools into the RSD on a wholesale basis. Meanwhile, city teachers were placed on "Disaster Leave without Pay," as the state superintendent hastily solicited federal aid from the Department of Education to open charters by January of 2006.

It was a perfect storm that created the conditions for a new relationship between state and capital in the implementation of privately run public schools, known as charters or "school choice." Today, something like $70 \%$ of New Orleans schools are in the RSD and run by numerous charter companies like KIPP, New Beginnings, and Choice Foundation, to name a few. The state of Louisiana describes these as "independent public schools that are free to be more innovative and are held accountable for improved student achievement."
Kristen Buras, in Charter Schools, Race, and Urban Space: Where the Market Meets Grassroots Resistance, sets out to turn the ideology of school choice on its head with an assessment of market-based reform from the bottom up. Based on interviews with teachers, students, and local activists and situated in the racial history of this region of the south, Buras argues charters have run roughshod over historically black poor and working-class communities in a redistribution of state power from public to private hands.

New Orleans, with its high population of black students, is a site of contention for black education nationwide. Buras locates this site within the racial composition and geography of New Orleans and argues that a process of accumulation through dispossession, a concept coined by David Harvey (2006), has benefitted white business elites at the expense of black students, families, and neighborhoods. By late 2005 there began a piling on of private interests and institutions committed to remaking the schools, from Teach for Americas (TFA) to the Cowen Institute for Public Education Initiatives at Tulane University. After Katrina, the social relations of race and class were reshaped within a state and federal framework as Baton Rouge became headquarters for officials to re-engineer the city and its schools.

\section{New Orleans, with its high population of black students, is a site of contention for black education nationwide.}

Movers to remake schools in the lower Ninth Ward assumed a wealthier and whiter city after the wreckage of Katrina. The geography of race and class in the Ninth Ward seems especially intense as a site of struggle: over the last decade the Bywater of the Upper Ninth has seen an emigration of hipsters and rapidly rising real estate prices with the feel of Williamsburg or Crown Heights in Brooklyn. In one chapter, Buras looks at successful local efforts to reopen Kings Elementary School in the lower Ninth after it was renovated in 2007. In another, she considers "counterstories on the Master's plan for Reconstruction"-e.g., the permanent closure of Douglass High School in the Bywater. Here she describes a local program started in 1998 called "Students at the Center" (SAC) that created a curriculum based on local history and social justice, resulting in the publication of a collection of student essays. SAC is an example of what Buras calls "a culture of caring" lost after Katrina. The building was surrendered to KIPP Renaissance High School, which reopened with an air-conditioned auditorium, an emphasis on college prep, and a "no excuses" code of discipline.

The historic space that was Douglass became KIPP Renaissance High School in 2010-2011. . . Douglass students would not be welcome to attend. Whose renaissance was this? Master planners and those consulted by the Bring New Orleans Back Commission, which called for the city to develop the nation's first charter school 
district, included the founder of KIPP; founder of Teach for America; founder of New Schools for New Orleans; and the Broad Foundation, Gates Foundation, and NewSchools Venture Fund. . Community-led education initiatives could have provided the basis for state investment of resources at Douglass, but instead the interests and visions of edu-businesses such as KIPP came first. (114-115)

New Orleans business leader and booster for charter reform Leslie Jacobs put it this way: "We decided to take failing schools away from the school district... And in doing that, local policies go away . . . So out comes the building, the students, the money and a fresh start." (35) Presto. It was a "fresh start" for foundations like Gates, Broad, and Fisher, investors like WalMart and Bloomberg. This confluence of forces is pictured in a remarkable diagram of arrows in all directions, pointing directly and indirectly to New Schools for New Orleans (NSNO), a charter school incubator. Foundations dumped $\$ 17.5$ million into charters, outdone by the USDOE at $\$ 28$ million, along with a flood of lesser contributions that have flowed to organizations and local groups connected in one way or another to charters.

\section{If you want to destroy a government program, defund it first so it can't work and the people won't want it, and then privatize it, as Noam Chomsky has observed, and the history of public education in this country is a prime example. The next task, according to Chomsky, is to shift the focus of public attention from a sense of civic engagement to a sense that schooling is someone else's burden.}

The sixth and final chapter, co-written with a local collective, takes to task a report by NSNO on education reform that touts New Orleans as a guide for cities. This discussion might well have begun the book; the authors sketch the history of desegregation and white flight from 1950 through 2000 and, along with it, the defunding of city schools that formed the historical prologue to charter reform. This policy ecology, as Buras calls it, is a reminder of Marx's observation that capitalism is a creative and destructive process. The deadly force of Katrina had the effect of an accelerant for state and private sources.

The discussion of dispossession is most interesting when the author looks from the top down at the feeding frenzy of interest groups that closed in after Katrina. But conceptually, the discussion is out of focus. Terms like "urban space economy" are invoked but never fleshed out, and Harvey's notion of accumulation by dispossession is not put to much use. Is it the case, as Buras contends, that the closing of New Orleans schools was racially motivated, or was closure a process whose effects have heightened existing inequalities along lines of race and class? (Incidentally, there is no discussion of how dispossession has disproportionately affected women in the working class.) One thinks of the fortune saved on teacher salaries and benefits, bargain-rate TFA recruits flowing in from out of town, the creation of flexible, just-on-time production (to coin a phrase from Harvey, 1989) made possible by the destruction of organized labor. In reference to the rehiring of teachers fired in the fall of 2005, one teacher said to Buras: "Evidently, there's an unwritten memo that says 'anyone making over $\$ 50,000$, don't hire them'." (141)

Buras contrasts the "culture of the education market" with the "culture of the community," its opposite number. But beneath the discussion of racial politics is a dichotomy between community and business, local and external, tradition and the market that doesn't capture the complexity of class and racial struggle on the ground. The "culture of caring" logic was lost on me, and Buras's point that local schools and homes here are "situated on sacred ground" (82) is stated as an article of faith.

Readers may also be interested in a different and differently detailed take on charters by a New Orleans journalist whose account focuses on the narratives of a student, a teacher, and a school administrator respectively. In Sarah Carr's Hope Against Hope: Three Schools, One City, and the Struggle to Educate America's Children, Carr concludes that New Orleans schools have improved in the decade since Katrina but warns that education is no panacea for poverty.

If you want to destroy a government program, defund it first so it can't work and the people won't want it, and then privatize it, as Noam Chomsky has observed, and the history of public education in this country is a prime example. The next task, according to Chomsky, is to shift the focus of public attention from a sense of civic engagement to a sense that schooling is someone else's burden. Whether this is the "Master's Plan" or a new scheme of flexible labor, it amounts to a consolidation of control in private hands and an upward redistribution of resources, one might say, welfare for the ruling class.

Much of the controversy over charters seems to focus on whether they are better or worse than public schools (Carr 2013). A number of recent studies show that, by the dubious measure of standardized test performance, the differences between charter and public schools are "significantly insignificant." Buras would argue that they are worse for wresting control from communities and ushering in accumulation through dispossession and a whitewashing of the system. Her account shows how the state has engendered redistribution of services by drawing on reservoirs of capital while communities of color take a back seat and corporate interests drive the bus. It remains to be seen whether recent new legislation returning New Orleans to a locally elected school board-but keeping intact charter control over hiring and teaching-is much more than a Trojan horse. Time will tell. 


\section{References}

Buras, Kristen L. Charter Schools, Race, and Urban Space: Where the Market Meets Grassroots Resistance. 2015. Routledge.

Carr, Sarah. Hope Against Hope: Three Schools, One City, and the Struggle to Educate America's Children. 2013. Bloomsbury.

"Charter Schools are a 'Salvation for Families,' Christie Says." March 4, 2016. New Jersey Dot Com.

Chomsky, Noam. 2016. Requiem for the American Dream. Directed by Peter Hutchison and Kelly Nykes.

Harvey, David. The Condition of Postmodernity. 1989. Blackwell.

Louisiana Department of Education. www.louisianabelieves.com

"New Orleans Plan: Charter Schools, With a Return to Local Control." The New York Times, May 10, 2016.

"Out of Control: The Systematic Disenfranchisement of African American and Latino Communities Through School Takeovers." August 2015. The Alliance to Reclaim our Schools. 